\title{
MODEL KEPEMIMPINAN MASA DEPAN INDONESIA DALAM PERSPEKTIF SIPIL DAN MILITER
}

\author{
Danny Permana \\ Analis Tata Ruang Pada Dinas Penataan Ruang Kota Bandung, \\ dannypermana78@gmail.com
}

\begin{abstract}
Abstrak
Penelitian ini bertujuan untuk menentukan Model Kepemimpinan Masa Depan Indonesia dari Perspektif Sipil dan Militer. Gaya kepemimpinan sangat mempengaruhi struktur di bawahnya. Fenomena yang terjadi saat ini adalah adanya calon pimpinan atau calon presiden dari kalangan militer dan sipil. Dimana karakter kepemimpinan yang dipelajari oleh calon pemimpin dari militer adalah karakter kepemimpinan militer, bukan karakter kepemimpinan sipil. Metode yang digunakan dalam penulisan ini adalah metode deskriptif analitik dengan pendekatan kualitatif, data dalam penelitian ini dikumpulkan melalui dokumentasi dengan cara observasi pustaka, dan untuk memperoleh kesimpulan yang valid, penyusun menggunakan analisis deduktif. Hasil penelitian ini antara lain bahwa tipe kepemimpinan harus terlebih dahulu melihat situasi dan kondisi. Ciri pemimpin yang berangkat dari kalangan sipil dianggap lebih merakyat melihat kondisi di Indonesia yang sedemikian majemuk dengan masyarakatnya. Jadi orang sipil lebih fleksibel karena berasal dari masyarakat sipil, sedangkan model kepemimpinan dalam perspektif militer di suatu negara adalah kepemimpinan yang berada di bawah kewenangan dan kepentingan dominasi institusi militer dan / atau negara yang menggunakan prinsip-prinsip disiplin yang kuat. . Otokrasi adalah sifat seorang pemimpin, berbeda dengan otokrasi yang merupakan sistem pemerintahan. Ketika situasi membutuhkan pemimpin dengan tipe otokratis, pemimpin harus otokratis. Penerapan dari kombinasi jenis kepemimpinan sipil dan militer, peran masyarakat umum juga penting dalam negara yang menganut sistem demokrasi dalam memilih calon pemimpin nasional, yaitu pemimpin yang visioner dan pro rakyat, tetapi tetap memiliki sikap yang tegas, konsisten dan memiliki komitmen, baik dari masyarakat sipil maupun yang berlatar belakang militer.
\end{abstract}

Kata Kunci: Model Kepemimpinan, Sipil, Militer

\begin{abstract}
This study aims to determine Indonesia's Future Leadership Model from a Civil and Military Perspective. The leadership style greatly influences the structural underneath. The current phenomenon is that there are candidates for leadership or presidential candidates from the military and civilians. Where the leadership character learned by future leaders from the military is the character of military leadership, not the character of civilian leadership. The method used in this writing is descriptive analytical method with a qualitative approach, the data in this study
\end{abstract}


were collected through documentation by means of literature observation, and to obtain valid conclusions, the compilers used deductive analysis. The results of this study include that the type of leadership should first look at situations and conditions. The characteristics of leaders who depart from civilian circles who are considered more populist see the conditions in Indonesia which are in such a way as with its pluralistic society. So civilians are more flexible because they originate from civil society, while the leadership model in a military perspective in a country is leadership under the authority and interests of the dominance of military institutions (military institutions) and/or the state which uses strong disciplinary principles. Autocracy is the nature of a leader, in contrast to autocracy which is a system of a government. When the situation requires a leader with an autocratic type, the leader must be autocratic. The implementation of a combination of civilian and military leadership types, the role of the general public is also important in a country that adheres to a democratic system in choosing future national leaders, namely a leader who is visionary and pro-people, but still has a firm, consistent attitude and can be committed, both from civilians and those with military backgrounds.

Keywords: Leadership Model, Civil, Military

\section{PENDAHULUAN}

Sepanjang perjalanan sejarah negara Indonesia dari masa pasca kemerdekaan hingga orde reformasi, meninggalkan catatan-catatan yang cukup menarik untuk dikaji kembali aseiring perkembangan tata kepemimpinan negara dan pemerintahan dari periode ke periode kepresidenan. Setiap pemimpin negara tersebut memiliki ciri khas dan gaya kepemimpinannya masing-masing yang berbeda satau sama lain. Suatu negara tertentu dengan sistem pemerintahan tertentu ternyata mampu mengekspreikan praktik kebijakan maupun realita politik yang sama sekali berbeda, terkadang menyimpang bahkan bertentangan dengan tata dan sistem ideal (Rudianto, 2006:65)

Pemimpin merupakan salah satu unsur yang sangat penting dalam melaksanakan suatu kegiatan. Pemimpin memiliki sikap kepemimpinan yang berbeda-beda. Menurut sutarto, kepemimpinan merupakan rangkaian kegiatan penataan berupa kemampuan mempengaruhi perilaku orang lain dalam situasi tertentu agar bersedia bekerja sama untuk mencapai tujuan yang telah ditetapkan ${ }^{1}$.

\footnotetext{
${ }^{1}$ Saliman. (tt). Kepemimpinan (Konsep, Pendekatan, dan Strategi). Yogyakarta: Universitas Negeri Yogyakarta.
} 
Gaya kepemimpinan sangat mempengaruhi struktural dibawahnya. Hal tersebut terjadi pada Presiden Republik Indonesia dari masa ke masa yang memiliki gaya kepemimpinan berbeda dan mempengaruhi struktural dibawahnya. Pada masa orde lama, Terjadi Perubahan Sistem Pemerintahan dari Presidensial menjadi Sistem Pemerintahan Parlementer dan kembali lagi ke UUD 1945. Hal ini menyebabkan terjadi ketidakseimbangan dalam dunia perpolitikan dimana terjadinya pergantian kabinet hingga tujuh kali. Akibat yang dapat dirasakan dari pergantian kabinet dalam waktu yang singkat menyebabkan masyarakat Indonesia pada saat itu hilang kepercayaan karena program-program kerja kabinet tidak dapat direalisasikan. Kemudian pada masa orde baru, Pemilihan Presiden pada masa itu terjadi tidak demokratis. Selain itu, terjadi penyimpangan seperti aspirasi masyarakat kurang didengar, semaraknya korupsi, kolusi, nepotisme, dan bertambahnya kesenjangan sosial. Pada masa orde baru ini Pegawai Negeri Sipil (PNS) ikut berpolitik, kemudian adanya Dwifungsi ABRI, yaitu ABRI memiliki kedudukan dalam pengambilan keputusan. Selanjutnya, pada masa reformasi terjadi perbaikan-perbaikan seperti mulai terjadi banyak pembenahan yaitu dibuatnya Undang-Undang yang mengatur tentang Anti Monopoli dan persaingan sehat, perubahan undang-Undang Partai Politik, dan yang paling penting adalah Undang-undang Otonomi Daerah yang mampu menahan gejolak disintegrasi yang telah diwarisi pada masa Orde Baru, mulai banyak partai politik yang berkembang.

Terjadi perubahan pada saat reformasi, yaitu bahwa demokrasi pancasila mulai dilakukan, yang ditandai dengan dihapuskannya Dwi fungsi ABRI yaitu, terdapat larangan bagi militer untuk ikut serta dalam politik untuk menjaga kenetralan bagi partai politik dan masyarakat, dan PNS tidak dapat berpolitik (Sridanti, 2014). Sehingga ABRI dan PNS kedudukannya bersifat netral.

Fenomena yang terjadi pada saat ini adalah adanya calon pemimpin atau calon presiden yang berasal dari militer dan sipil. Adanya calon pemimpin dengan kekuatan militer yang masih dapat dikatakan kuat, terjadi karena masih terdapat post power syndrome, yaitu adanya keyakian bahwa calon pemimpin dari militer masih memiliki kapabilitas sebagai peimimpin bangsa. Dimana karakter 
kepemimpinan yang dipelajari oleh calon pemimpin dari militer adalah karakter kepemimpinan militer bukan karakter kepemiminan sipil.

Selain itu para mantan anggota militer yang mencalonkan diri sebagai pemimpin kurang memikirkan bahwa yang dipimpin adalah masyarakat secara luas bukan hanya militer saja. Tetapi, adanya militer dalam politik dapat memberikan keuntungan yang sangat penting yaitu munculnya strategi-strategi untuk mengurus negara.

Pemimpin merupakan salah satu unsur yang sangat penting dalam melaksanakan suatu kegiatan. Pemimpin memiliki sikap kepemimpinan yang berbeda-beda. Menurut Sutarto, kepemimpinan merupakan rangkaian kegiatan penataan berupa kemampuan mempengaruhi perilaku orang lain dalam situasi tertentu agar bersedia bekerja sama untuk mencapai tujuan yang telah ditetapkan. Dari definisi tersebut dapat dipahami bahwa kepemimpinan merupakan kegiatan mempengaruhi oleh seorang pemimpin kepada orang lain untuk mencapai suatu tujuan tertentu.

Pada dasarnya kepemimpinan mengandung kesamaan pemahaman bahwa kepemimpinan adalah kemampuan seseorang dalam mempengaruhi orang lain untuk mencapau tujuan bersama yang positif, juga adanya unsur-unsur orang yang memimpin, yang dipimpin, adanya organisasi dan adanya tujuan yang ingin dicapai bersama.

Arti pemimpin adalah seorang pribadi yang memiliki kecakapan dan kelebihan, khususnya kecakapan/kelebihan di satu bidang sehingga dia mampu mempengaruhi orang-orang lain untuk bersama-sama melakukan aktivitas-aktivitas tertentu demi pencapaian satu atau beberapa tujuan (Kartono:1994).

Pendapat lain menjelaskan pemimpin adalah seorang yang memimpin dan mengarahkan orang lain sehingga orang yang dipimpin itu mematuhinya dengan sukarela. Setiap orang yang berfungsi memimpin, membimbing dan mengarahkan orang lain adalah seorang pemimpin (Effendi, 1986:206).

Menurut Siagian (2009:12-13) terdapat lima peran pemimpin yaitu:

1. Penentu arah, yaitu pemimpin menentukan araj tujuan organisasi dalam pengambilan keputusan dan pemimpin merupakan salah satu faktor yang 
mendorong untuk dapat mewujudkan visi dan misi yang dilakukan secara terencana dan bertahap.

2. Wakil dan juru bicara organisasi, yaitu pemimpin berperan sebagai wakil dan juru bicara organisasi dalam menjalin komunikasi dengan pihak atau instansi lain.

3. Komunikator, yaitu kemampuan seorang pemimpin untuk mengkomunikasikan berbagai sasaran, strategi, tindakan atau keputusan yang diambil baik secara lisan maupun tertulis untuk disampaikan kepada para pelaksana kegiatan operasional atau bawahan melalui jalur komunikasi yang terdapat dalam organisasi.

4. Mediator, yaitu kemmapuan seorang pemimpin dalam menyelesaikan situasi konflik yang mungkin timbul dalam suatu organisasi, maupun lingkungannya tanpa mengurangi pentingnya situasi konflik yang mungkin timbul dalam hubungan keluar yang dihadapi maupun yang diatasi.

5. Integrator, yaitu pemimpin yang berfungsi sebagai penyatu dari berbagai individu dan kelompok yang berbebda pola pikir menuju pada tujuan bersama.

Seorang pemimpin dengan bawahannya harus menciptakan hubungan yang baik untuk memperoleh dukungan dan kepercayaan yang maksimal dalam kepemimpinannya. Dalam hal ini seorang pemimpin harus dapat menunjukkan reputasi yang baik, memiliki kinerja yang baik, dan dapat mengatasi problemproblem yang dihadapu oleh bawahannya. Fungsi kepemimpinan dapat disimak sebagaimana yang dikemukakan oleh Hadari Nawawi (1996:76) yaitu:

1. Fungsi Instruktif ada;ah fungsi kepemimpinan yang bersifat komunikasi satu arah, kepemimpinan yang efektif memerlukan kemampuan menggerakkan dan memotivasi orang lain agar tergantung pada pemimpin.

2. Fungsi konsultatif yakni fungsi yang berlangsung dan bersifat dua arah meskipun pelaksanaan sangat tergantung pada pemimpin.

3. Fungsi partisipatif yakni fungsi yang tidak sekedar berlangsung atau bersifat dua arah, tetapi juga berwujud pelaksanaan hubungan manusia efektif, antara pemimpin dengan orang yang sesama dipimpin.

4. Fungsi pengendalian yaitu fungsi yang cenderung komunikasi satu arah meskipun komunikasi tidak dilkaukan dengan dua arah.

Adapun tipe kepemimpinan dalam literatur terdapat beberapa macam teori dan masing-masing literatur saling melengkapi. Di antara literatur yang membahas tipe kepemimpinan yang dapat digunakan oleh seorang pemimpin dalam kepemimpinannya adalah sebagai berikut: 


\section{Tipe Kepemimpinan Otokratis}

Tipe kepemimpinan yang mendasarkan diri pada kekuasaan dan paksaan yang mutlak harus dipatuhi. Pemimpin semacam ini ingin berkuasa penuh dalam berbagai situasi dan dalam menjalankan roda pemerintahannya tanpa konsultasi dengan bawahannya. Kepemimpinan otokratis itu berdasarkan kekuasaan dan paksaan yang mutlak dan biasanya yang dikembangkan dalam kegiatannya hanya melaksanakan perintah atasan, sementara bawahan tidak diberi kesempatan untuk berinisiatif dan mengeluarkan pendapat-pendapat. Dalam kepemimpinan otokratis seorang pemimpin sangat egois, menentukan kebijakan, dan mengambil keputusan menurut kehendaknya sendiri, dan juga dapat disebut pemimpin diktator. Tipe kepemimpinan semacam ini memiliki keuntungan yaitu kedisiplinan sangat tinggi dan dapat mengontrol pekerjaan bawahannya dengan mudah. Adapun kekurangannya yaitu bawahan tidak memiliki kreatifitas, dikarenakan tidak memiliki kesempatan untuk berpartisipasi dan pengambilan keputusan untuk perkembangan organisasi (Nawawi:2003).

2. Tipe Kepemimpinan Paternalistik

Tipe kepemimpinan paternalistik yaitu tipe kepemimpinan yang kebapakkan dengan sifat-sifat:

a. Dia menganggap bawahannya sebagai manusia yang tidak/belum dewasa, atau anak sendiri yang perli dikembangkang.

b. Dia bersikap terlalu melindungi (overly protective)

c. Jarang dia memberikan kesempatan kepada bawahannya untuk mengambil keputusan sendiri.

d. Dia hampir-hampir tidak pernah memberikan kesempatan kepada bawahannya untuk berinisiatif.

e. Dia tidak pernah memberikan atau hampir-hampir tidak pernah memberikan kesempatan pada pengikutinya dan bawahannya untuk mengambangkan imajinasi dan daya kreativitas mereka sendiri.

f. Selalu bersikap maha tau dan maha benar (Kartono:1994).

3. Tipe Kepemimpinan Karismatik

Sondang P. Siagian (2003:37) menjelaskan bahwa tipe kepemimpinan kharismatik adalah suatu tipe kepemimpinan yang memiliki karakteristik yang khas yaitu daya tariknya yang sangat memikat sehingga mampu memperoleh pengikut 
yang jumlahnya kadang-kadang sangat besar. Tegasnya seorang pemimpin yang kharismatik adalah seseorang yang dikagumi oleh banyak pengikut meskipun para pengikutnya tidak selalu dapat menjelaskan secara kongkret mengapa orang tertentu itu dikagumi.

Melihat penjelasan itu pemimpin kharismatik memiliki kekuatan yang sangat baik dalam menarik dan memengaruhi bawahan atau orang lain. Melalui kekuatan itu sangat mungkin menggaet orang/pengikut yang sangat besar jumlahnya. Selaras dengan ungkapan Kartini Kartono tipe kepemimpinan kharismatik adalah tipe kepemimpinan yang memiliki kekuatan energi, daya tarik, dan pembawa yang luar biasa untuk memengaruhi orang lain, sehingga ia mempunyai pengikut yang sangat besar jumlahnya dan pengawal-pengawal yang bisa dipercaya.

\section{Tipe Kepemimpinan Laisser Faizer}

Tipe kepemimpinan ini dipersepsi bahwa roda pekerjaan organisasi diserahkan pada bawahannya. Seorang pemimpin memberikan keleluasaan pada bawahan dan menganggap bawahannya orang yang dewasa, sehingga pemimpin tidak perlu intervensi terhadap perjalanan organisasi. Di sini sang pemimpin percaya penuh pada bawahan atas keberhasilan, tujuan, dan sasaran yang hendak dicapai organisasi. Tipe kepemimpinan semacam ini dikatakan oleh Sondang P. Siagian (2003:38) bahwa seorang pemimpin dalam perannya memiliki pandangan pada umumnya organisasi akan berjalan lancar dengan sendirinya, karena para anggota organisasi terdiri dari orang-orang yang sudah dewasa yang mengetahui segala sesuatu tujuan organisasi, sasaran organisasi, tugas para anggotanya, dan pemimpin tidak perlu melakukan intervensi kehidupan organisasi. Sejalan dengan itu Kartini Kartono (1994:76) menjelaskan bahwa kepemimpinan laizzes faire ditampilkan oleh seorang tokoh ketua dewan yang sebenarnya tidak becus mengurus dan dia menyerahkan semua tanggung jawab serta pekerjaan kepada bawahan atau kepada semua anggotanya. Tipe kepemimpinan Laissez Faire yaitu pemimpin berkedudukan sebagai simbol karena dalam realita kepemimpinannya dilakukan dengan memberikan kebebasan sepenuhnya pada orang yang dipimpin untuk berbuat dan mengambil keputusan secara perseorangan. Puncak pimpinan 
dalam menjalankan kepemimpinannya hanya berfungsi sebagai penasehat dengan memberikan kesempatan bertanya manakala merasa perlu

5. Tipe Kepemimpinan Demokratis

Tipe kepemimpinan ini sangat berbeda dengan tipe kepemimpinan otokrasi yang mendasarkan pada kekuasaan, sedangkan tipe kepemimpinan demokratis melibatkan bawahan yang harus melaksanakan keputusan. Hal ini sesuai penjelasan Kartini Kartono bahwa tipe kepemimpinan demokratis adalah kepemimpinan yang berorientasi pada manusia dan memberikan bimbingan yang efisien kepada para pengikutnya. Juga dapat dipahami definisi kepemimpinan demokratis yaitu pemimpin yang partisipatif berkonsultasi dengan bawahan tentang tindakan dan keputusan yang diusulkan serta mendorong adanya keikutsertaan bawahan. Jalannya kepemimpinan demokratis ditandai dengan adanya suatu struktur yang pengembangannya menggunakan pendekatan pengambilan keputusan yang kooperatif Di bawah kepemimpinan demokratis bawahan cenderung bermoral tinggi, dapat bekerja sama, mengutamakan mutu kerja dan dapat mengarahkan diri sendiri. Dalam kepemimpinannya demokratis seorang pemimpin lebih mengutamakan kepentingan bersama dari pada kepentingan individu dan golongan. Dasar utama dalam kepemimpinannya melakukan musyawarah dan kekeluargaan dalam menyelesaikan masalah dan terciptalah iklim kerja yang sehat, saling membantu, dan saling pengertian di antara mereka.

Adanya gaya kepemimpinan tersebut sangat mempengaruhi struktural dibawahnya. Hal tersebut terjadi pada Presiden Republik Indonesia dari masa ke masa yang memiliki gaya kepemimpinan berbeda dan mempengaruhi struktural dibawahnya. Pada masa orde lama, Terjadi Perubahan Sistem Pemerintahan dari Presidensial menjadi Sistem Pemerintahan Parlementer dan kembali lagi ke UUD 1945. Hal ini menyebabkan terjadi ketidakseimbangan dalam dunia perpolitikan dimana terjadinya pergantian kabinet hingga tujuh kali. Akibat yang dapat dirasakan dari pergantian kabinet dalam waktu yang singkat menyebabkan masyarakat Indonesia pada saat itu hilang kepercayaan karena program-program kerja kabinet tidak dapat direalisasikan. Kemudian pada masa orde baru, Pemilihan Presiden pada masa itu terjadi tidak demokratis (Ridanti:2012). 
Dari sistem pemerintahan yang dinamis dari masa ke masa tersebut, maka dapat dikatakan cocok bagi pemimpin pada masa orde lama yang memiliki gaya kepemimpinan yang kharismatik, memiliki semangat pantang menyerah dan rela berkorban demi persatuan dan kesatuan serta kemerdekaan Bangsanya. Kemudian pada masa orde lama, yang memiliki gaya kepemimpinan yang cenderung otoriter, karena pergolakan politik yang terjadi. Serta pada masa orde baru, yang sebagian besar pemimpinnya memiliki gaya kepemimpinan yang demokratis. ${ }^{2}$ Kecocokan gaya kepemimpinan tersebut dapat dilihat dari situasi dan budaya masyarakat pada masa tersebut.

Saat ini, Indonesia pada masa reformasi. Pada masa ini, globalisasi mulai timbul dan sangat mempengaruhi masyarakat. Indonesia merupakan negara dengan penduduk yang beragam sehingga disebut negara dengan masyarakat majemuk. Menurut Furnivall, masyarakat majemuk adalah masyarakat yang terdiri dari dua atau lebih elemen atau tatanan sosial yang hidup berdampingan, namun tanpa membaur, dalam suatu unit politik (Hefiner:2007). Dari definisi tersebut, dapat dipahami bahwa Indonesia merupakan negara dengan masyarakat yang majemuk, yaitu memiliki kebudayaan yang berbeda-beda tetapi tetap hidup berdampingan.

Menurut Berghe, ciri-ciri masyarakat majemuk adalah ketiadaan konsensus nilai-nilai, beranekaragam kebudayaan, terjadi konflik di antara kelompok yang berlainan, otonomi atau kebebasan di antara bagian-bagian dalam sistem sosial, diperlukan paksaan dan saling ketergantungan dalam ekonomi sebagai dasar integrasi sosial, terjadi dominasi politik oleh golongan-golongan tertentu, serta relasi antarkelompok lebih merupakan secondary segmental dan utilitarian, sedangkan relasi dalam kelompoknya lebih merupakan primary. Dalam kehidupan politik, Handoyo (2015) menyatakan bahwa pertanda yang paling jelas dari masyarakat Indonesia yang bersifat majemuk adalah tidak adanya kehendak bersama (common-will) Berdasarkan penjelasan tersebut dapat dipahami bahwa masyarakat Indonesia merupakan masyarakat yang majemuk dan memiliki

2 Scholachudin. (tt). Gaya Kepemimpinan Presiden di Indonesia [online]. Tersedia: https://www.academia.edu/33001135/GAYA_KEPEMIMPINAN_PRESIDEN_DI_INDONESIA diakses pada tanggal 16 Januari 2021 
kehendak bersama. Dalam kehidupan politik, masyarakat Indonesia dapat dilihat dari budaya politik masyarakat.

Selanjutnya Riyanto (2006) mengemukakan bahwa budaya politik cenderung dipahami sebagai sikap dan perilaku (tindakan) politik individu atau kelompok dalam kehidupan politik dalam suatu sistem politik (political system). Terdapat jenis-jenis budaya politik, yaitu:

1. Budaya Politik Partisipan

Budaya politik partisipan memiliki arti masyarakat sudah memiliki tingkat kesadaran budaya politik yang begitu tinggi, hal ini didasari oleh tingkat pendidikan yang sudah tinggi pula. Masyarakat jenis ini sering kita jumpai di negara-negara maju. Menurut Almond dan Verba, budaya politik yang partisipasif adalah budaya politik yang demokratik, dalam hal ini, akan mendukung terbentuknya sebuah sistem politik yang demokratik dan stabil. Budaya politik yang demokratik ini menyangkut "suatu kumpulan sistem keyakinan, sikap, norma, persepsi, dan sejenisnya, yang menopang terwujudnya partisipasi. Budaya politik partisipan (participant political culture), yaitu budaya politik yang ditandai dengan kesadaran politik sangat tinggi.

\section{Budaya Politik Kawula}

Budaya politik kawula merupakan tingkat budaya politik yang dimana masyarakatnya sudah relatif maju namun kesadaran atau partisipasi dalam dunia politik masih kurang. Budaya politik kawula juga bisa disebut dengan budaya politik subjek. Meskipun masyarakatnya sudah relatif maju dalam urusan dan ekonomi dan sosial namun tingkat kesadaran akan budaya politik masih cenderung berkurang, contohnya saja Indonesia.

\section{Budaya Politik Parokial}

Budaya politik parokial merupakan budaya politik yang kesadaran (partisipasi) masyarakatnya masih sangat rendah, hal ini dikarenakan tingkat pendidikan yang rendah pula. Budaya politik semacam ini biasanya masih terjadi di negara-negara tertinggal dan sebagian negara berkembang (Riyanto:2006).

Saat ini, budaya politik masyarakat Indonesia yang majemuk dapat dikategorikan dengan budaya politik kawula-partisipan. Hal tersebut terjadi karena 
masyarakat Indonesia sudah mulai terbuka karena pengaruh adanya globalisasi dan masyarakat Indonesia merupakan masyarakat majemuk yang cenderung tidak memiliki kehendak yang sama, dalam arti masyarakat Indonesia sudah memiliki pola pikir yang berbeda-beda.

Dengan adanya masyarakat Indonesia yang majemuk dan budaya politik yang sudah melekat di masyarakat, yaitu budaya politik kawula-partisipan, maka diperlukan pemimpin yang sesuai dan memiliki tipe kepemimpinan yang cocok untuk diterapkan pada masyarakat Indonesia. Oleh karena itu, diperlukan analisis dan pemahaman mengenai calon pemimpin yang cocok bagi masyarakat Indonesia. Sehingga Indonesia dapat mencapai tujuan-tujuannya dengan baik.

Metode dalam penelitian ini ialah deskriptif analitis dengan pendekatan kualitatif. Materi pembahasan didasarkan pada kajian pustaka buku-buku dan berbagai karya tulis ilmiah yang membahas mengenai model kepemimpinan negara dalam perspektif sipil dan militer dalam konteks pembentukan tata pemerintahan negara. Penelitian mendeskripsikan mengenai konsep kepemimpinan sipil dan militer untuk kemudian dianalisis secara logis sehingga mendapatkan suatu kesimpulan model kepemimpinan nasional dalam perspektif sipil dan militer.

Data dalam penelitian ini dikumpulkan melalui dokumentasi dengan cara observasi kepustakaan, yaitu mencari data mengenai obyek penelitian yang berkaitan dengan konsep-konsep kepemimpinan sipil dan militer dalam suatu negara. Untuk memperoleh kesimpulan yang valid, maka penyusun mempergunakan analisis deduktif, yaitu dengan cara menganalisa data umum yang ada dalam beberapa lliteratur, kemudian diklasifikasikan dalam beberapa kelompok sehingga dapat ditari menjadi suatu kesimpulan.

\section{PEMBAHASAN}

Pemimpin merupakan salah satu unsur yang sangat penting dalam melaksanakan suatu kegiatan terutama dalam mengatur sebuah negara. Pemimpin memiliki sikap kepemimpinan yang berbeda-beda. Maka dari itu pemimpin yang baik adalah pemimpin yang bisa menghimpun semua masyarakatnya untuk bisa memberikan kesempatan yang sama dalam segi pemerintahan. 
Sondang P Siagian mengemukakan terdapat lima tipe kepemimpinan yakni Otokratik, Paternalistik, Karismatik, Laissez Faire, dan Demokratik.

\section{Perspektif Sipil}

Indonesia saat ini sedang memasuki era reformasi, dimana pada saat ini globalisasi mulai timbul dan sangat mempengaruhi kehidupan masyarakat. Indonesia merupakan negara majemuk yang terdiri dari banyak suku, bangsa, dan etnis. Dengan melihat hal tersebut, Indonesia sebagai negara yang majemuk dan di era reformasi ini lebih cocok untuk dipimpin oleh pemimpin sipil dengan tipe demokratis.

Hal ini karena sifat kepemimpinan militer berbeda dengan sipil. Dalam militer tidak ada kerangka mengenai demokrasi tersebut. Apabila pemimpin berangkat dari kalangan militer maka pemimpin diperkirakan memiliki sikap militer yakni otoriter karena pengaruh kedisiplinan militer yang tinggi dan terpaku pada perintah satu arah (komando). Sedangkan dari kalangan sipil lebih fleksibel karena berawal dari masyarakat sipil, sedangkan kalangan militer lebih baik fokus pada bidang pertahanan dan keamanan negara.

Pemimpin yang menggunakan gaya kepemimpinan otokratik sesuai apa yang dikatakan oleh Sutikno (2014) bahwa tipe kepemimpinan adalah hak pribadinya, sehingga tidak perlu berkonsultasi dengan orang lain dan tidak boleh ada orang yang turut campur tangan (Sutikno:2014). Dengan demikian, seorang pemimpin yang tergolong otokratik memiliki serangkaian karakteristik yang biasaya dipandang sebagai pemimpin yang egois. Hal ini berbeda dengan karakteristik pemimpin yang berangkat dari kalangan sipil yang dinilai lebih merakyat melihat pada kondisi Indonesia yang sedemikian rupa dengan masyarakatnya yang majemuk.

Sifat terkotak-kotak yang ada di masyarakat berpendapat dan intinya manusia memang pada dasarnya memiliki sikap yang terkotak-kotak, yakni akan bergabung dengan kelompok yang memiliki tujuan atau suatu kepentingan yang sama. Manusia akan menentukan ke arah mana dirinya akan berpikir, mengonsep, bergerak dan merubah sesuatu. 
Pemerintahan tidak hanya berfokus pada masalah ketatanegaraan dan kejahatan yang mengancam, yang kemudian membuat rakyat seakan terombangambing karena sikap dan karakter pemimpinnya yang otokratik yang biasanya dengan karakteristik seperti itu digunakan untuk mendoktrin rakyat agar timbul rasa takut terhadap pemimipinnya. Machiavelli (Budiardjo, 2008) pernah menyebutkan bahwa tidak adanya keshahihan bagi militer untuk memegang kekuasaan di negara republik. Hal ini karena sama saja dengan membiarkan perpanjangan pemerintahpemerintah militer yang nantinya akan mendorong pertumbuhan paksi yang akan mengalahlan kepentingan publik itu sendiri.

\section{Perspektif Militer}

Model kepemimpinan dalam perspektif militer dalam sebuah negara ialah kepemimpinan yang mempunyai kaitan erat dan kecenderungan pada praktikpraktik kepemimpinan yang menerapkan prinsip, nilai-nilai, ideologi, wacana dan perilaku militer yang meliputi komado, hirarkhi, disiplin, keseragaman, dan lainnya. Adapun kepemimpinan negara dibawah wewenang dan kepentingan dominasi institusi militer (lembaga militer) dan/atau negara yang menggunakan prinsip-prinsip kedisiplinan yang kuat dalam proses ketatanegaraan baik langsung maupun tidak langsung.

Tipe kepemimpinan sebaiknya harus melihat terlebih dahulu pada situasi dan kondisi. Ketika situasi dalam keadaan yang membutuhkan pemimpin dengan tipe otokratik, maka pemimpin harus bersifat otokratik. Dengan demikian, pemimpin otokratik dibutuhkan dan memiliki nilai yang cukup penting karena pada dasarnya pemimpin itu harus bisa tegas dan menyesuaikan dengan situasi dan kondisi di Indonesia yang seringkali timbul pergesekan.

Kedisiplinan yang terkandung dalam konsep militerisme merupakan kekerasan akibat dan dampak dan mindset perang. Adapun kekerasan yang ditimbulkan akibat dominasi militer diantaranya prinsip, ideologi, dan nilai-nilai yang di usung berdasarkan perspektif militer cenderung tegas, keras, kaku, hirarkis dan tersistematis (Komando/Perintah), bukan tanggung jawab atau kompromi. Sehingga militer sering berbelok dari profesionalismenya sebagai alat negara, menyelamatkan negara dalam konteks keamanan negara. Hal itulah yang seringkali 
dijadikan alasan untuk mendominasi masyarakat, dan terlibat dalam urusan-urusan politik bernegara demi kepentingan kelompok, golongan atau institusinya, bahkan dapat disalah gunakan sebagai alat penguasa semata.

Tipe militer otokratik dapat diimplementasikan dengan terlebih dahulu melihat situasi dan kondisi yang terjadi di masyarakat maupun negara. Hal ini lebih dilakukan pada saat situasi dan kondisi tersebut membutuhkan pemimpin yang bertipe otokratik, bukan artinya bersikap egois dan tidak menerima masukan, bukan berarti memiliki sistem yang otokrasi. Perlu diketahui bahwa otokrasi adalah sifat pemimpin yang nantinya bisa mempengaruhi orang lain. Berbeda dengan otokrasi yang merupakan sistem dari sebuah pemerintahan. Hal ini didukung dengan bahwa otokrasi tersebut merupakan gaya kepemimpinan semata. Melihat fakta di Indonesia saat ini, pemimpin yang seperti apapun masih bersikap mengkotakkotakkan kepentingan sesuai dengan kelompok masyarakat, dan masih mementingkan pemikiran dan kepentingan kelompoknya juga.

Dalam sistem militerisasi dipelajari bagaimana caranya agar seorang pemimpin memimpin dengan tegas dan disiplin. Ketika militer masuk ke ranah politik praktis, maka dalam kepemerintahannya militer akan menampilkan gaya kepemimpinan yang sudah tertanam.

Dapat dikatakan bahwa kepemimpinan militer bukan berarti mengekang atau membatasi kebebasan masyarakat. Hal ini berdasarkan kondisi demokrasi saat ini dimana banyak pemimpin yang kurang dihargai dan menurunnya wibawa serta rasa hormat dimata masyarakat. masyarakat terlalu bebas berpendapat mengenai apapun yang sebenarnya sudah dengan usaha dan jalan yang maksimal dilakukan oleh pemerintah. Sedangkan otoriter itu masyarakat akan lebih takut kepada pemerintah. Takut dalam hal ini buka berarti takut dan agar selalu tunduk pada pemerintah, tapi lebih memiliki rasa segan kepada para pemimpin.

Berdasarkan hal tersebut maka harus adanya profesionalitas dua arah, harus disikapi jangan sampai membawa militer kearah politik praktis, tentu harus disikapi secara negawarasan oleh pihak politisi, sipil dan militer. Kedua pihak jangan sampai memanfaatkan fenomena itu untuk kepentingan kelompok yang nantinya justri akan merusak reformasi militer dan demokrasi. Misalnya politik sipil 
berupaya menarik militer kearah politik praktis, kemudian membangun wancana untuk mengembalikan hal politik militer, ataun dengan pihak-pihak yang ada di jalur politik praktis seperti partai politik dan bakal calon pemimpin. Pada dasarnya kedua pihak tersebut berbeda, dimana militer merupakan sebuah kesatuan yang memiliki dan menanamkan sifat dan sikap yang tegas. Pada saat menjadi pemimpin maka akan menerapkan sifat dan sikap tersebut dalam banyak situasi dan kondisi yang terjadi di Indonesia.

Selain hal yang telah dipaparkan mengenai tipe pemimpin, dapat dilihat juga pada sektor birokrasi. Ketika membahas mengenai kepemimpinan mana yang lebih baik, otokratik atau demokratik, sipil maupun militer, namun dapat dilihat para demokrat pun masih banyak yang berlaku seakan banyak bernegosiasi dan menyelewengkan nilai-nilai demokrasi. Adapun faktanya di negara-negara maju di duani ialah negara-negara yang memiliki kekuatan militer yang cukup tinggi, dimana memiliki ketegasan dan kedisiplinan tinggi. Contohnya Amerika Serikat serta Korea Utara dengan sistem komunisnya. Dengan begitu militerisasi dapat mewujudkan keamanan masyarakat dengan mentertibkan dan membuat disiplin berbagai bidang di Indonesia yang akan mendukung Indonesia menjadi negara maju.

Pada dasarnya, masyarakat sudah memiliki tugas dan fungsinya masingmasing, baik di lingkungan sekitarnya, pekerjaan, pemerintahan, kesatuan, keamanan, ataupun di pertahanan. Tentunya akan lebih baik dengan adanya perpaduan antara kepemimpinan sipil dan militer, dan juga antara gaya kepemimpinan, baik otokrasi dan/atau demokrasi. Hal ini dapat dicontohkan dengan adanya pemimpin negara yang berasal dari kalangan sipil, sedangkan wakilnya berasal dari kalangan militer, ataupun sebaliknya. Dengan begitu akan tetap ada kepemimpinan demokrasi dan otokrasi dari perspektif sipil maupun militer.

Hal ini dapat berkaca pada era pemerintahan orde baru yang kental dengan sistem militerisasi, dan dampaknya positifnya terlihat adanya keberhasilankeberhasilan seperti pembangunan dan ketertiban yang tercipta pada era Orde Baru. Dengan demikian, untuk sekarang dan masa yang akan datang dapat 
diimplementasikan kembali untuk menciptakan situasi yang tetap dalam sistem demokrasi namun kesan militer dalam aspek-aspek tertentu.

Mengenai kolaborasi kepemimpinan antara sipil dan militer dalam segi kepemimpinan, bagi masyarakat sipil merupakan hal yang dirasa cukup sulit beradaptasi dengan kepemimpinan militer. Hal ini terjadi karena masyarakat sipil cukup sulit untuk ditegasi. Maka sekalipun sedang dalam kepemimpinan militer, maka pemimpin tetap saja harus memiliki solusi untuk mengatasi ketegasannya antara memimpin sesama militer dan saat memimpin masyarakat sipil. Terutama dengan kondisi masyarakat Indonesia yang majemuk.

Selain diadakannya perpaduan antara tipe kepemimpinan sipil dan militer, serta pembuatan undang-undang yang mengaturnya, adanya peran dari masyarakat umum juga penting di negara yang menganut sistem demokrasi dalam memilih pemimpin bangsa di masa yang akan datang, yakni pemimpin yang berpihak pada rakyatnya dan berjiwa pahlawan yang tujuan kepemimpinannya ditujukan untuk kemakmuran bangsanya.

Melihat situasi dan kondisi demokrasi pada saat ini dapat dikatakan terlalu bebas sehingga menimbulkan kesan masyarakat yang kurang percaya pada pemerintah yang menerapkan tipe kepemimpinan demokratik. Para pejabat negara banyak dijadikan bahan ejekan oleh rakyat yang bahkan hal ini urang mendapat respon penanganan yang berarti, hal ini cukup menggambarkan demokrasi yang terlalu bebas terutama dalam hal berpendapat. Demokrasi yang telalu bebas ini juga ditandai dengan adanya organisasi-organisasi yang diluar dugaan malah menjadi bumerang, seperti organisasi-organisasi yang ingin mengikis Pancasila sebagai ideologi di negara ini.

\section{KESIMPULAN}

Berdasarkan pembahasan yang telah dipaparkan, bahwa tipe kepemimpinan sebaiknya harus melihat terlebih dahulu pada situasi dan kondisi. Karakteristik pemimpin yang berangkat dari kalangan sipil yang dinilai lebih merakyat melihat pada kondisi Indonesia yang sedemikian rupa dengan masyarakatnya yang majemuk. Maka kalangan sipil lebih fleksibel karena berawal dari masyarakat sipil, 
sedangkan kalangan militer lebih baik fokus pada bidang pertahanan dan keamanan negara. Adanya kepemimpinan dari kalangan sipil yakni untuk memutus perpanjangan pemerintah-pemerintah militer yang nantinya akan mendorong pertumbuhan paksi yang akan mengalahlan kepentingan publik itu sendiri.

Sedangkan model kepemimpinan dalam perspektif militer dalam sebuah negara ialah kepemimpinan dibawah wewenang dan kepentingan dominasi institusi militer (lembaga militer) dan/atau negara yang menggunakan prinsip-prinsip kedisiplinan yang kuat dalam proses ketatanegaraan baik langsung maupun tidak langsung. Otokrasi adalah sifat pemimpin yang nantinya bisa mempengaruhi orang lain. Berbeda dengan otokrasi yang merupakan sistem dari sebuah pemerintahan. Ketika situasi dalam keadaan yang membutuhkan pemimpin dengan tipe otokratik, maka pemimpin harus bersifat otokratik, dalam artian tegas dan disiplin.

Pada dasarnya, masyarakat sudah menempati dan memiliki peran dan fungsinya masing-masing dalam suatu negara, baik itu masyarakat sipil maupun militer, keduanya memiliki sisi positif dan negatifnya masing-masing. Selain diadakannya perpaduan antara tipe kepemimpinan sipil dan militer, serta pembuatan undang-undang yang mengaturnya, adanya peran dari masyarakat umum juga penting di negara yang menganut sistem demokrasi dalam memilih pemimpin bangsa di masa yang akan datang, yakni pemimpin yang berpihak pada rakyatnya dan berjiwa pahlawan yang tujuan kepemimpinannya ditujukan untuk kemakmuran bangsanya. Dengan begitu, pemimpin yang cocok untuk masa depan ialah pemimpin yang visioner dan berpihak pada rakyat, namun juga tetap memiliki sikap tegas, konsisten dan dapat berkomitmen baik itu dari kalangan sipil maupun yang berlatas belakang militer.

\section{DAFTAR PUSTAKA}

Budiardjo, Miriam. (2008). Dasar-dasar Ilmu Politik. Jakarta: Gramedia Pustaka Utama

Effendy, Mochtar. (1986). Manajemen Suatu Pendekatan Berdasarkan Ajaran Islam. Jakarta: Bhratara Karya Aksara

Ginintasasi, R. (tt). Kepemimpinan. Bandung: Universitas Pendidikan Indonesia. 
Handoyo, A. (2015). Studi Masyarakat Indonesia. Yogyakarta: Penerbit Ombak.

Hawari, Hadari. (1996). Administrasi Pendidikan. Jakarta: PT Gunung Agung (2003). Kepemimpinan Mengefektifkan Organisasi. Yogyakarta: Universitas Gajah Mada University Press

Hefner, R. (2007). Politik Multikulturalisme: Menggugat Realitas Kebangsaan. Yogyakarta: Institute for Multicuturalism and Pluralism Studies.

Kartono, Kartini. (1994). Pemimpin dan Kepemimpinan. Jakarta: Raja Grafindo Persada

Kirbiantoro, S. Dody Rudianto. (2006). Pergulatan Partai Politik di Indonesia: Nasionalisme-Islamisme-Komunisme-Militerisme. Jakarta: Intermedia Publisher.

Riyanto, A. (2006). Budaya Politik Indonesia. Bandung: Pasca Sarjana Universitas Pendidikan Indonesia.

Saliman. (tt). Kepemimpinan (Konsep, Pendekatan, dan Strategi). Yogyakarta: Universitas Negeri Yogyakarta.

Scholachudin. (tt). Gaya Kepemimpinan Presiden di Indonesia. Diakses pada 16 Januari 2021.

Academia: https://www.academia.edu/33001135/GAYA KEPEMIMPINAN PRESI DEN_DI_INDONESIA

Siagian, Sondang P. (2009). Manajemen Sumber Daya Manusia Untuk Perusahaan dari Teori dan Praktek. Jakarta: Rajawali Press

Sridanti, L. (2014). Materi Perkuliahan Sistem Pemerintahan RI. Bali: STISIP Margarana Tabanan.

Sugiyono. (2014). Metodologi Penelitian Kualitatif Kuantitatif dan $R \& D$. Bandung: Alfabeta CV.

Sutikno, Sobry M. (2014). Pemimpin dan Gaya Kepemimpinan. Lombok: Holistica 